the conflict" appears to mean the probability that the trustee could profit from the situation; and "feebleness" of the inducement, the size of the profit to be obtained. The two together determine the single question of whether the particular facts of the case indicate a substantial possibility that the trustee would violate his trust. Where no such possibility exists, the trustee should not be held liable unless the beneficiaries can sustain the burden of showing bad faith. ${ }^{42}$

12 Cf. Pine v. White, 175 Mass. 585, 56 N.E. 967 (1900).

\title{
APPRECIATION DAMAGES FOR SELF-PURCHASE BY TRUSTEE WITH POWER OF SALE
}

When a trustee with power of sale ${ }^{1}$ sells trust property to himself in breach of trust, the beneficiary has alternative remedies. Unless the property is held by a bona fide purchaser, the beneficiary may compel reconveyance. If it can be shown that a bona fide purchaser has intervened, reconveyance will be denied; but irrespective of this showing, it is clear that the beneficiary may recover either the amount by which the value of the property at the time of the trustee's purchase exceeded the purchase price, or the trustee's profits on the transaction. ${ }^{2}$ It is not clear, however, that the beneficiary is confined to these remedies; some authority exists for allowing him the additional option of recovering "appreciation damages" _ the present value of the property less the trustee's

1 Where the trustee lacks power of sale, appreciation damages are clearly proper, for the reason that, had the trustee not violated his duty to retain, the appreciated property would still be in the trust estate. 2 Scott, Trusts $\$ 208$ (2d ed., 1956); 1 Rest., Trusts $\$ 208$ (1935). A possible objection to this result is that it allows the beneficiary to use the courts for "speculation." See note 21 infra.

2 The beneficiary's options are listed in 2 Scott, op. cit. supra note 1 , at $\$ \S 170.2,206$; 3 Bogert, Trusts and Trustees $\S 484$ (1935).

There exists the possibility of an additional option: following the trustee's profits into their product. To do so would require at least that the trustee consciously acted wrongfully, 2 Scott, op. cit. supra note 1 , at $\$ 507$, and that the proceeds could be isolated from the trustee's general assets. Locke v. Old Colony Trust Co., 289 Mass. 245, 193 N.E. 892 (1935). See notes 8 and 19 infra.

${ }^{3}$ Treatise authority for the imposition of appreciation damages can be found in Scott and the Restatement. Neither authority, however, is free from equivocation; in the Restatement, in fact, the equivocation is so strong that it might be cited as contrary authority.

In 2 Scott, op. cit. supra note 1 , at $\$ 206$ (Liability for Breach of Duty of Loyalty), at page 1532, Scott states: "If the trustee sells trust property to himself individually, and subsequently resells the property to a third person, the beneficiaries have the option of charging him with the value of the property at the time of sale with interest, or with the value of the property at the time of the suit, or they can hold him accountable for the proceeds." (emphasis added.) Nevertheless, in section 170.2 (Duty of Loyalty: Remedies of the Beneficiaries) there is no mention of appreciation damages.

Section 205(h) of the Restatement provides: "If the trustee commits a breach of trust, he is chargeable with ... (c) any profit which would have accrued to the trust estate if he had not committed such breach of trust." Under the language of $\S 205$ (c), appreciation damages can be justified only if it is assumed (1) that had the trustee not first sold to himself, he would 
credits. ${ }^{4}$ Where the trustee resells shortly after purchase from the trust, and the beneficiary learns of the transaction many years later, the difference in the measure of damage could reach an astronomical figure.

Although the trustee-and the fiduciary generally-has often been held accountable for his profits, ${ }^{5}$ appreciation damages have rarely been awarded, or even claimed by the beneficiary, ${ }^{6}$ in cases where the trustee has had power

not have sold to the bona fide purchaser, and (2) that he never would have sold the property to anyone else or would have sold it at a time so close to the present that the present value of the property would represent a fair approximation of its value at the date of hypothetical resale. See Stewart v. Joyce, 205 Mass. 371, 374, 91 N.E. 555, 556 (1910).

The commentary to the Restatement also implies that $\$ \$ 205$ and 206 were not intended to confer appreciation damages. $\$ 206$, Comment b (Sale of Trust Property to the Trustee Individually), does not include appreciation damages among the beneficiary's options. Comment $b, \S 208$, states that that section imposing appreciation damages for sale in violation of duty to retain does not apply to other sales in breach of trust. Section 205, Comment $h$, the only comment explaining clause (c), lists only three situations to which the clause is applicable: sale in breach of duty to retain, failure to purchase when directed to do so, and failure to make trust property productive.

This last situation suggests the relation of Section 205(c) to Section 206. The trustee, having purchased trust property, must account not merely for the rents and profits actually received during the period of his ownership, but also the profits which would have been received under careful management. Accord: West v. Waddill, 33 Ark. 575 (1878); Fricker v. Americus Mfg. \& Imp. Co., 124 Ga. 165, 52 S.E. 65 (1905); In re Jenning's Estate, 74 Mont. 449, 241 Pac. 648 (1925). Contra: Van Buskirk v. Van Buskirk, 148 Ill. 9, 35 N.E. 383 (1893). On this interpretation, the Restatement would not limit the beneficiary to the proceeds the trustee actually received on resale, but would allow to be recovered the amount which would have been received had the resale been prudently made. See note 34 infra.

Some doubt as to this interpretation might be raised by $\S 291(1)(b)$, allowing appreciation damages against a purchaser with notice of the trustee's breach, irrespective of good faith. See $\$ 291$, Comment $g$. There seems to be no reason to treat a trustee less stringently than his transferee.

In McKim v. Hibbard, 142 Mass. 422, 8 N.E. 152 (1886), the date of commencement of suit was the date from which damages were determined. Other methods of computation, however, are possible. In McCord v. Nabours, 101 Tex. 494, 109 S.W. 913, 111 S.W. 144 (1908), the court referred to "the time of trial." The Restatement of Trusts uses the date of decree. Rest., Trusts $\$ 208$ (1935). Scott would allow either the date of commencing suit or the date of decree, whichever would give the benefiary greater recovery. 2 Scott, op. cit. supra note 2 , at $\S 208.3$. The differences between these methods of computation will be disregarded in this comment.

5 E.g., Van Landingham v. Cruce, 152 Ark. 562, 239 S.W. 25 (1922); Crenshaw v. Seeley, 129 Cal.App. 627, 19 P.2d. 50 (1933); Boswell v. Cunningham, 32 Fla. 277, 13 So. 354 (1893); Hopkins v. Loeber, 332 Ill.App. 140, 74 N.E.2d 39 (1947); Byington v. Moore, 62 Iowa 470,17 N.W. 644 (1883); Ricketts and Whittington v. Montgomery, $15 \mathrm{Md} .46$ (1860); Meade v. Vande Voorde, 139 Neb. 827, 299 N.W. 175 (1941); Wendt v. Fischer, 243 N.Y. 439, 154 N.E. 303 (1926); Durand v. Preston, 26 S.D. 222, 128 N.W. 129 (1910); Hapgood v. Jennison, 2 Vt. 294 (1829); Stewart v. Baldwin, 86 Wash. 63, 149 Pac. 662 (1915). Other cases can be found in 2 Scott, op. cit. supra note 1 , at $\$ 170.2 ; 3$ Bogert, op. cit. supra note 2 , at $\$ 484$.

- In two cases appreciation damages were sought and recovered: McCord v. Nabours, 101 Tex. 494, 109 S.W. 913, 111 S.W. 144 (1908); McKim v. Hibbard, 142 Mass. 422, 8 N.E. 152 (1886). The McKim case involved outright conversion by the trustee; there was no evidence that the trustee replaced the trust property with anything of value, or had any intention to do so. Cf. Sullivan v. Ramsey, 155 S.W. 580 (Tex. Civ. App., 1913). 
of sale. Moreover statutes, which appear on their face to authorize appreciation damages, have not been used for this purpose. ${ }^{7}$ The facts in some cases indicate that appreciation damages would not have represented the maximum recovery to the beneficiary, ${ }^{8}$ yet in a significant number of cases the contrary must have been true. ${ }^{9}$ Thus the paucity of cases litigating the issue of appreciation damages raises at least some inference of an assumption by the bar that such damages are inappropriate.

Two arguments can be advanced favoring imposition of appreciation damages. The first asserts that a trustee's purchase of trust property is but one instance of sale in violation of a duty to retain, a breach for which appreciation damages are clearly a proper remedy..$^{10} \mathrm{~A}$ trustee is under a duty to retain except where he has been given power of sale." It is certain, the argument runs, that the settlor did not intend to confer upon the trustee the power to make illegal sales. Sale to self is unlawful, and so outside the powers conferred in the trust instrument. Therefore the trustee has violated a duty to retain. But

7 The California Civil Code has the following provision: "A trustee who uses or disposes of the trust property [for his own profit] may, at the option of the beneficiary, be required to account for all profits so made, or to pay the value of its use, and if he has disposed thereof, to replace it, with its fruits, or to account for its proceeds with interest." Cal. Civ. Code (Deering, 1949) $\$ 2237$ (emphasis added). Montana has an identical provision. Mont. Rev. Code Ann. (1947) $\$ 86-310$. Cf. S.D. Code (1939) \$59.0107. No cases in which appreciation damages are sought have been found in either Montana or South Dakota.

When the trustee has had power of sale, California courts have not awarded appreciation damages, despite the wording of the statute. This opposition to appreciation damages may have been carried unreasonably far in Clapp v. Vatcher, 9 Cal.App. 462 , 99 Pac. 549 (1908). In defiance of a court order, defendant sold the property to a bona fide purchaser at only 80 per cent of its then market value. Thereafter it appreciated 75 per cent. In her complaint, desiring to bring her action within the scope of $\$ 2237$, plaintiff alleged that defendant had converted the proceeds to his own use. The court held that by this allegation, plaintiff had elected to sue for the proceeds with interest. Thus, the California statute may have the effect of giving the beneficiary less protection than under common law. See note 1 supra.

Louisiana has enacted $\S 205$ of the Restatement. La. Rev. Stat. (1951) $\S 9: 2033$. As to whether $\$ 205$ is an authority supporting appreciation damages, see note 3 supra. The point has not been litigated in Louisiana.

8 This would be the case in the following situations: (a) the property has depreciated after resale, In re Walsh Ex'rs, 126 Misc. 479, 214 N.Y.Supp. 167 (Surr. Ct., 1926); Hayward v. Ellis, 13 Pick. (Mass.) 272 (1832); (b) the proceeds plus interest may be greater than the appreciation, see Buffim v. Peter Barcelous Co., 289 U.S. 227, 237 (1933); (c) the beneficiary may be able to establish a constructive trust on the trustee's profits, which may have appreciated more than the original property, Locke v. Old Colony Trust Co., 289 Mass. 245, 193 N.E. 892 (1935). As to possibility (c), see note 2 supra.

- The fact that the trustee, even after the value of his improvements are deducted (see note 29 infra and accompanying text) was able to realize a profit on resale indicates the property has appreciated between sale to self and resale, assuming the trustee paid a fair price. In such a case, there is a good possibility that the property has continued to appreciate after resale.

${ }^{10}$ See note 1 supra. But see Rest., Trusts $\$ 208$ (1935), imposing appreciation damages for violation of duty to retain; Comment $b$ states that the section is not intended to apply to other breaches of trust.

I 2 Scott, op. cit. supra note 1 , at $\$ 190$. 
this argument would mean that a trustee whose sole breach was in selling to third persons for too low a price ${ }^{12}$ or who failed to exercise independent judgment ${ }^{13}$ would also be liable for appreciation damages. Assuming for the moment that the purpose of damages for breach of trust is to make the beneficiary whole, ${ }^{14}$ it would seem that when a trustee who is justified in making a sale sells to himself rather than to a third person, the injury to the beneficiary, if any, is the difference between the price paid and the price which could have been obtained on the market, not the appeciation in the value of the property. ${ }^{15}$ This initial conclusion, however, must undergo further consideration.

The second argument for imposition of appreciation damages builds upon the unchallenged right of the beneficiary to compel reconveyance unless the property has been transferred to a bona fide purchaser. ${ }^{16}$ Appreciation damages represent the monetary equivalent of reconveyance. To deny the beneficiary these damages merely because the trustee has sold to a bona fide purchaser would be to allow the trustee to determine his own measure of damages and would force the beneficiary to affirm the trustee's sale to the bona fide purchaser. There would seem to be no reason to distinguish the case where the sale is directly to the bona fide purchaser, a sale which the beneficiary clearly must affirm, and the case in which the trustee intervenes as a temporary owner. But the validity of this second argument must depend not on mechanical analogy, but rather on the reason for the rule which allows the beneficiary to compel reconveyance. It may be suggested that reconveyance is included among the beneficiary's options because so long as the property remains in the trustee's possession there remains a possibility of the trustee realizing a profit on his purchase of the trust property. Thus reconveyance or its monetary equivalent is irrelevant once the property passes out of the trustee's hands.

A technical argument can be adduced against imposition of appreciation damages. When a trustee purchases trust property, it is said that he becomes a constructive trustee to the use of the beneficiary and that he is therefore to reconvey and account for his profits. ${ }^{17}$ This theory cannot be used to justify appreciation damages. No one can be a trustee in vacuo; a constructive trust

12 "If the trustee is guilty of a breach of trust in selling trust property for an inadequate price, he is liable for the difference between the amount he should have received and the amount which he did receive. $H e$ is not liable, however, for any subsequent rise in value of the property sold." 2 Scott, op. cit. supra note 1 , at $\S 208.6$ (emphasis added). See also Rest., Trusts $\S 205$, Comment d (1935).

13 Appreciation damages denied: In re Talbot's Estate, 141 Cal.App.2d 309, 296 P.2d 848 (1956), noted in Liability of the Trustee for Appreciation of Property, 4 U.C.I.A. I. Rev. 314 (1957).

14 See 3 Bogert, op. cit. supra note 2, at $\$ 481$.

${ }_{15}^{15}$ See discussion of Rest., Trusts $\S 205$ (c) (1935), in note 3 supra.

${ }^{26}$ See note 2 supra and accompanying text.

173 Bogert, op. cit. supra note 2 , at $\S 484 ; 4$ Scott, op. cit. supra note 1 , at $\$ 497$; Rest., Restitution \& 192 (1937). 
can be declared only over property to which the constructive trustee has legal title. ${ }^{18}$ Once the property passes to a bona fide purchaser, it ceases to be part of the constructive trust, and is replaced by the proceeds of resale. ${ }^{19}$ In an action on constructive trust theory, the beneficiary would thus be limited to the proceeds as the measure of recovery.

Another argument can be adduced against award of appreciation damages. Within the time allowed by the doctrine of laches, ${ }^{20}$ the beneficiary can defer suit until the property reaches a high value. Courts have been hostile to remedies which permit a plaintiff deliberately to use the courts to take advantage of market fluctuation. ${ }^{21}$

The arguments against appreciation damages become particularly forceful when it is recognized that in many of these cases the trustee has acted in good faith. A trustee may purchase trust property for a wide variety of motives. Among these motives two extremes might be conscious desire to sacrifice the beneficiary's interest for personal gain ${ }^{22}$ and the desire to protect the beneficiary by increasing the present value of the property. ${ }^{23}$ Aside from these extremes of

183 Bogert, op. cit. supra note 2 , at $\$ 471$, p. 3 n. 1 .

19 See note 2 supra.

${ }^{20}$ Scott, op. cit. supra note 2 , at $\$ 219$. It might be argued that the doctrine of laches could be employed to protect the beneficiary from excessive appreciation damages. It has been stated that it is essential to a defense of laches to show defendant's prejudice from plaintiff's lethargy in commencing suit. Brissell v. Knapp, 155 Fed. 809 (D. Nev., 1907). In Bibler v. Bibler, 205 Iowa 639, 216 N.W. 99 (1927), the fact that the property had appreciated during the intervening period was cited as one reason for sustaining the defense of laches to an action for reconveyance. In Winn v. Shugart, 112 F.2d 617 (C.A. 10th, 1940), the court stated that laches would occur within a particularly short period in an action for reconveyance of property capable of rapid fluctuation. Nevertheless, in determining laches, the time factor has traditionally predominated over other equitable factors. See 2 Scott, op. cit. supra note 2 , at $\$ 219$. Mioreover if laches were employed as a protection against excessive damages, high appreciation would defeat a beneficiary's entire action, even though brought within what would normally be considered a reasonable time. To protect the beneficiary some doctrine of "partial laches" would have to be created.

21 This problem arose when courts were considering the measure of damages to be imposed on a pledgee wrongfully converting stock. Fear of speculation by the pledgor caused opposition to the rule allowing the pledgor the highest intermediate value between conversion and commencement of suit. "This is not an equitable rule and it has not been satisfactory to most courts. It not only permits the customer to speculate at the expense of the broker, but it assumes he would have sold at exactly the right moment; thus it guarantees to him the highest profits. In addition, it permits him to lengthen the period of speculation by delaying the action." Annotation, Measure of Damage for Broker's Breach of Contract with Customer as to Sales and Purchases of Stocks on the Exchange, 1917C L.R.A. 747,748-49. The words of the annotator are relevant to the issue of appreciation damages with but one qualification: the beneficiary seeking appreciation damages is under risk of loss if the property should depreciate while he postpones action.

${ }^{22}$ See MrKim v. Hibbard, 142 Mass. 422, 8 N.E. 152 (1886); Hart v. Ten Eyck, 2 Johns. Ch.(N.Y.) 62 (1816).

${ }^{23}$ See Hapgood v. Jennison, 2 Vt. 294 (1829) (The trustee purchased trust land at a tax sale with the intent to strengthen the title through vendue sale; there was no concealment and the probate court was notified.). 
motive, there occur various types of activity where neither harm nor benefit to the beneficiary is anticipated, such as simple misunderstanding of the law forbidding self-purchase, ${ }^{24}$ belief that acquisition of the trust property would be a proper compensation for services rendered in behalf of the trust estate, ${ }^{25}$ or ignorance that the property purchased was part of the trust estate. ${ }^{26}$ Thus the purchase of trust property does not invariably involve "moral turpitude"; indiscriminate imposition of appreciation damages without proof of bad faith cannot be justified as a method of punishing the trustee. It is significant that punishment is not a reason for the beneficiary's other remedies, as can be seen from the unavailability of good faith as a defense to an action for surcharge in self-dealing cases. ${ }^{28}$

If a trustee has acted in good faith, appreciation damages might still be justified as a deterrent to self-dealing. Deterrence is the rationale for permitting the beneficiary to sue for reconveyance or for the trustee's profits even though the net result of the transaction was advantageous to the trust estate. To neither action can the trustee answer that he has paid fair value or more for the property. The trustee is held liable because dealing with the trust estate necessarily involves a division of loyalties; even though the temptation is scrupulously avoided, the community may indulge in hostile surmises. By taking from the trustee the chance of profit on the transaction while requiring him to bear the risk of loss, this conduct is thought to be deterred. Further deterrence appears to be necessary; that the present remedies are sufficient seems implicit in the general rule that the trustee who has acted in good faith is allowed credits for improvements on self-purchased property, ${ }^{29}$ and is charged with simple interest rather than compound, at the going rate rather than the legal rate when the former is lower. ${ }^{30}$

More stringent methods of deterrence may be needed against a trustee who has acted in bad faith. ${ }^{31}$ Appreciation damages might supply this needed strin-

24 See e.g., Dilworth's Appeal, 108 Pa. 92 (1885); Morse v. Hill, 136 Mass. 60 (1883).

${ }^{25}$ Pomeroy v. Bushong, $317 \mathrm{~Pa} .459,177$ Atl. 10 (1935) (purchase by executor of stock belonging to trust after procurement of loan for trust by posting of executor's individual property as security).

${ }^{26}$ This could result from the complexities of large-scale trust company organization. So, too, a corporate trustee might mistakenly sell to one of its own departments. See Corporate Trustee's Conflict of Interest, 25 U. of Chi. I. Rev. 382 (1958); Recent Interpretations of Self Dealing, 20 B.U.L. Rev. 766 (1940), noting in re Binder's Estate, 137 Ohio St. 26, 27 N.E.2d. 939 (1939).

${ }^{27}$ In re Talbot's Estate, 141 Cal.App. 2d 309, 327, 296 P.2d. 848, 859 (1956); Rest., Restitution $\$ \S 198,202$ (1937).

${ }^{28} 2$ Scott, op. cit. supra note 1 , at $\$ 170.1 ; 3$ Bogert, op. cit. supra note 2 , at $\S 484$, at p. 99. This is corroborated by the fact that surcharge remains unaffected in jurisdictions which have expressly rejected the doctrine of punitive damages.

394 Scott, op. cit. supra note 1 , at $\$ 479.1$.

${ }^{30} 2$ Scott, op. cit. supra note 1 , at $\$ 207$.

${ }^{31}$ It has been argued that the less scrupulous the potential offender, the more severe must be the penalties for the offense. Michael and Wechsler, Cases on Criminal Law and its Adminis- 
gency. While in any particular case, appreciation after resale may be small, the possibility of large appreciation damages may deter a trustee contemplating. appropriation of trust property, especially if his expectation was that the property would later appreciate to permit profits on resale. Moreover, the trustee's bad faith in the initial transfer suggests the possibility of a collusive transfer between the trustee and the purported bona fide purchaser. ${ }^{32}$ However, it may be pointed out that there already exist sanctions peculiarly applicable to the trustee who has acted in bad faith. For example, in his accounting certain credits are disallowed, ${ }^{33}$ and in proper cases criminal sanctions exist. ${ }^{34}$ Thus the question of imposing appreciation damages on a trustee who has acted in bad faith is a close one. However, it is clear that, in the absence of bad faith, appreciation damages would be an unduly severe measure, unnecessary for adequate protection of beneficiaries.

tration 159-61 (1940). If the trustee is acting in bad faith he may be more likely to conceal his purchase and thereby make discovery and accountability less likely, with the result that more stringent penalties are needed to achieve adequate deterrence. See 3 Bogert, op. cit. supra note 2, at 100 n.55, quoting from Conway v. Green's Adm'r, 1 Har. \& J. (Md.) 151, 152 (1801).

${ }^{32}$ Assume a case where the trustee, having appropriated the property, now senses that the beneficiary will soon discover the breach and compel reconveyance. If the trustee believes the property will appreciate, a bogus transfer accepted by the court at face value would defeat the action for reconveyance, thereby permitting the trustee to take advantage of the appreciation. Where there is no evidence that the trustee has acted in bad faith, there is less reason to infer a collusive transfer. A clear showing of bona fide transfer would defeat the inference in either case.

${ }^{33}$ See notes 29 and 30 supra.

34 2 Bishop, Criminal Law c.16 (9th ed., 1923).

Even if a rule surcharging bad faith trustees for appreciation damages is rejected, the measure of relief should be based not on the resale price, but on the market value on the date of resale, because bad faith trustees may be willing to sell at a low price in an endeavor to avoid discovery or to obtain cash for further speculation. This is apparently the rule in Pennsylvania. Powers v. Black, $159 \mathrm{~Pa} .153,28 \mathrm{Atl} .133$ (1893). Where the trustee has acted in good faith throughout, there seems to be a presumption that he received a fair price on resale. Id., at 157, 134. But cf. Ricketts and Whittington v. Montgomery, $15 \mathrm{Md} .46$ (1860).

The Pennsylvania rule solves the troublesome problem of a trustee who sold to himself at a time when sale was proper but who sold to a bona fide purchaser at a time when the market was such that the property should have been retained. The situation is extremely hypothetical, particularly in view of courts' hesitancy to find a duty to retain solely on market or expected market. See In re Guaranty Trust Co. of New York, 188 Misc. 61,69 N.Y.S.2d 416 (Surr. Ct., 1945); Rest. Trusts $\$ 208$, Comment b (1935). Nevertheless, absent this presumption, appreciation damages would be a proper remedy.

\section{THE POWER OF AN ADMINISTRATIVE AGENCY TO ATTACH TERMS AND CONDITIONS TO OFFICIAL ACTION}

Administrative agencies have frequently achieved extensive regulation of matters apparently beyond their statutory authority by attaching terms and conditions to official action. For example, the Civil Aeronautics Board for 